STATE OF ILLINOIS

DEPARTMENT OF REGISTRATION AND EDUCATION DIVISION OF THE

NATURAL HISTORY SURVEY

STEPHEN A. FORBES, Chief

Vol. XiII. BULLETIN Article XIII.

\title{
FURTHER TESTS OF DRY SULFUR COMPOUNDS FOR THE CONTROL OF THE SAN JOSE SCALE
}

BY

WESLEY P. FLINT

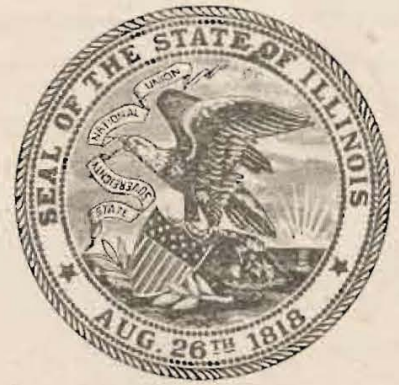

PRINTED BY AUTHORITY OF THE ST ATE OF ILLINOIS

URBANA, ILLINOIS

November, 1920 


\section{ERRATA}

Page 97, line 17, for first larval read pupal.

Page 112, in legend, for jonessi read jonesii.

Page 114, in legend', for or read of.

Page 125, line 4, for Bonosa read Bonasa.

Page 131, in legend, for hirundinaceus read hirudinaceus.

Page 138, last line, for coccoon read cocoon.

Plate XII, explanation page, next to last line, for acrivora read aerivora.

Plate XIII, explanation page, next to last line, for White-grubs read White-grub.

Page 293, Figure $5 a$ was reversed in printing, and the two items of the legend should change places.

Page 515, second table, for Pelocoris femorata read Pelocoris femoratus. 
ArTiCLE XIII.-Further Tests of Dry Sulfur Compounds for the Control of the San Jose Scale. By Wesley P. Flint.

\section{INTRODUCTION}

During the season of 1919 a series of experinents for the control of the San Jose scale was conducted in two orchards on the west side of the state. The object of these experiments was to make a thorough test, under field conditions, of several widely advertised dry sulfur compounds intended for the control of the San Jose scale. A description of these experiments and the results have been published in Experiment Station Circular No. 239, this work being conducted by IV. S. Brock, of the Horticultural Department of the University of Illinois, and the present writer. During the season of 1920 the work in the Quincy orchard was continued and slightly enlarged, but that in the Barry orchard was abandoned for lack of funds.

The dry sulfur compounds, especially the dry lime-sulfurs, have several advantages over the conmercial lime-sulfur solutions, for orchard use. Some of these advantages are that the dry material is not subject to leakage; does not deteriorate with freezing; is much cheaper to ship and easier to haul; and is much handier to work with, especially for the small orchardists.

For a better understanding of these experiments the description and results of the work done in 1919 are first given in full.

\section{LOCATION AND CONDITION OF ORCHaRDS}

The orchards selected for the experiments are near Barry, Pike county, and Quincy, Adams county.

The orchard in Pike county is located one and one-half miles west of Barry and contains about forty acres of mature Ben Davis trees. The block selected in the Barry orcliard adjoins an Osage hedge which was probably the original source of the scale infestation. The trees nearest the hedge were incrusted and, untreated, would almost certainly have failed to survive the season of 1919. At a distance of two hundred feet from the hedge the infestation was not quite so serious, but many of the limbs were incrusted. The plots were arranged to include each degree of infestation, and were as nearly uniform as possible.

The orchard near Quincy, situated two miles east of the city, on the farm of Wm. Hausemann, consisted of six acres of seventeen-year 
old trees of mixed varieties, Ben Davis and Grimes predominating. There was a uniformly heavy infestation of the scale throughout the orchard, all trees showing some limbs incrusted. The majority of these trees would probably not have survived the season of 1920 if no treatment had been given.

\section{Materials Used}

The materials used and the strength of each spray were as follows:

Commercial concentrated lime-sulfur $33^{\circ}$ Baumé, 1 gallon to 8 gallons of water

Scalecide, 1 gallon to 15 gallons of water

B. T. S., 14 pounds to 50 gallons of water

Niagara soluble sulfur, $121 / 2$ pounds to 50 gallons of water

Sherwin-Williams dry lime-sulfur, 15 pounds to 50 gallons of water

Dow dry lime-sulfur, 15 pounds to 50 gallous of water

\section{Time and Method of Application}

Barry Orchard.-The sprays were applied March 28, 1919, with a "Bean" duplex power outfit at a minimum pressure of 250 pounds. There was a brisk west wind which made it necessary to use a spray gun in order to make the application from all sides of the trees. The tops of the trees were covered by a rod, and whirlpool disc nozzles were operated from the tower. The gun was operated from the ground.

The weather was warm and the first leaves were beginning to show green. About nine gallons of material were used to each tree.

Quincy Orchard.-The sprays were applied March 2\%, 1919, with a "Friend" power outfit, using from 250 to 275 pounds' pressure. The tops and upper sides of the branches were sprayed with a gun from the tower, the under sides being covered with a rod used from the ground. A third man stood at a little distance from the sprayer to call attention to any parts of the tree that were missed. In this way, a very thorough application was made to all parts of the trees, about eleven gallons of solution being used per tree.

The weather was warm, with bright sum and a light wind. The leaf buds were just bursting, nearly all of them showing a little green.

\section{Results}

The orchards were graded July 21 and 22 by both experimenters, working independently, neither knowing the kind of treatment applied to the plots except in the orchard under his personal supervision. Each tree in a given plot was graded separately, and a general average for the plots was determined. The results were then compared and tabulated as shown in the following table. 
SAN Jose Scale Experments, 1919

\begin{tabular}{|c|c|c|c|}
\hline \multirow{2}{*}{$\begin{array}{l}\text { Plot } \\
\text { No. }\end{array}$} & \multirow{2}{*}{ Treatment } & \multicolumn{2}{|c|}{ Control } \\
\hline & & Barry & Quincy \\
\hline 1 & Commercial lime-sulfur solution, 1 gallon to $\mathrm{S}$ & & \\
\hline 2 & 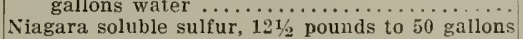 & & \\
\hline 3 & 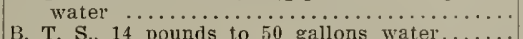 & Excellent & Excellent \\
\hline 4 & Sherwin-Williams dry lime-sulfur, 15 pounds to & Falr & \\
\hline 5 & Dow dry lime-sulfur, 15 pounds to 50 gallons & Excellent & Excellent \\
\hline $\begin{array}{l}6 \\
7\end{array}$ & $\begin{array}{l}\text { Scalecide, i gallon to } 15 \text { gallons water... } \\
\text { Check: unsprayed }\end{array}$ & Excellent & Excellent \\
\hline
\end{tabular}

In the above table the terms used indicate that a plot graded as "Fair" showed a considerable number of live scales present on all parts of the tree and fruit; "Good" indicates scattered living scales fairly easy to find, but not numerous enough to cause marked blemishes on the fruit or injury to the trees; and "Excellent" indicates living scales difficult to find and no blemishes on the fruit.

\section{ADDITIONAL IVORK IN 1920}

In the spring of 19:0 the same orchard at Quincy was again treated, plots $1,2,3,4$, and 5 being given the sane application as in 1919 . Plots if and $i$ were sprayed with Martin-Senour's dry lime-sulfur at the rate of $121 / 2$ pounds to 50 gallons of water. A check plot of three trees was left on the east side of the orchard, these trees having been sprayed in 1919 with liquid lime-sulfur, one to eight. The spray was applied on March 29 and 30 . The days were warn and bright, with a moderately high wind from the northwest. The leaf buds were just beginning to show the green. The spraying was done with a "Friend" power outfit, using from 200 to 250 pounds" pressure, the spray being applied with two rods, one used from the top of the tank and the other from the ground. All the trees were sprayed as thoroughly as possible.

The orchard was graded on Jume 11 by five men, working independently, only one of whom knew the treatments which had been given. The plots were again exanined and graded on Atg. 11 and Sept. 22 , to note any increase in the number of scales. Results of these gradings were compared and tabulated as in 1919.

On Aug. 11, fifty leaves were picked at random from different parts of the trees in each plot, and examined for living scales.

On Sept. 2?, one hundred apples on each plot were examined for the presence of the scale. These results may be somewhat misleading from the fact that the number of scales on all of the apples where less than $20 \%$ 
showed the scale, was very small, very few of the apples being sufficiently infested to cause a blemish.

The results of these examinations are shown in the following table.

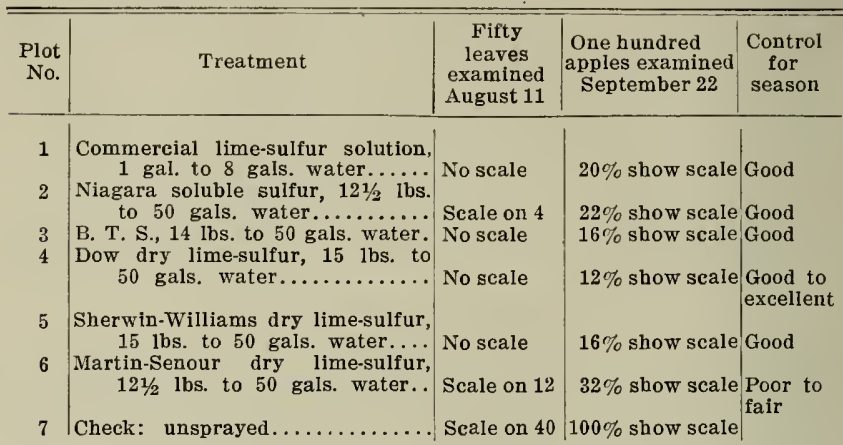

In addition, a spray was applied to an older orchard composed entirely of $2 \tilde{\jmath}$-year old Ben Davis trees. These trees had been badly neglected and over half of the orchard was dead, the remaining trees being almost entirely incrusted and showing numerous dead branches. This orchard was treated in the following manner:

Plot 1--Commercial lime-sulfur solution, 1 gal. to 8 gals. water 2 -Niagara soluble sulfur, $12 \frac{1}{2}$ lbs. to 50 gals. water

3 -B. T. S., 14 lbs. to 50 gals. water

4-Dow dry lime-sulfur, $15 \mathrm{lbs}$. to .50 gals. water

5-Sherwin-Williams dry lime-sulfur, 15 lbs. to 50 gals. water

6-Martin-Senour dry lime-sulfur, $121 / 2$ lbs, to 50 gals. water

7-Check: unsprayed

This orchard was carefully examined on June 11, and.again on Sept. 22. The scale was still numerous on many of the heaviest infested trees, as it would be impossible to clear up this orchard entirely with one treatment. A summary of the results obtained from this grading is as follows.

\begin{tabular}{|c|c|c|}
\hline $\begin{array}{l}\text { Plot } \\
\text { No. }\end{array}$ & Treatment & $\begin{array}{l}\text { Control for } \\
\text { season }\end{array}$ \\
\hline $\begin{array}{l}1 \\
2 \\
3 \\
4 \\
5 \\
6 \\
7\end{array}$ & 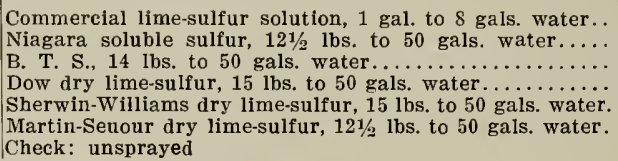 & $\begin{array}{l}\text { Good } \\
\text { Fair to good } \\
\text { Fair to good } \\
\text { Good } \\
\text { Good } \\
\text { Very poor }\end{array}$ \\
\hline
\end{tabular}


The results of two years' work with these materials seem to show that some dry sulfur compounds, if used at sufficient strength, are effective in controlling the San Jose scale. From the results of the past season where Martin-Senour's dry lime-sulfur was used at a strength of $12 \mathrm{I} / 2 \mathrm{lbs}$, to 50 gallons of water, it is apparent that these materials should not be used at a less rate than $15 \mathrm{lbs}$. to 50 gallons of water. 